\title{
H2BC8 Gene
}

National Cancer Institute

\section{Source}

National Cancer Institute. H2BC8 Gene. NCI Thesaurus. Code C162930.

This gene plays a role in histone-dependent transcription regulation, DNA repair, DNA

replication and chromosomal stability. 